\title{
chulieieva 0. INVESTIGATION OF ELECTROPHYSICAL PROPERTIES OF NANOMODIFIED FIREPROOF EVA POLYMER COMPOSITIONS
}

Об’єктом дослідження є електрофізичні властивості пожежобезпечних композиційних матеріалів етилену з вінілацетатом, до складу яких входять наповнювачі-антипірени та модифікатори. Однією з найбільших проблем є зміни електрофізичних властивостей пожежобезпечних композиційних матеріалів в залежності від хімічних властивостей та дисперсності наповнювачів-антипіренів та модифікаторів. 3 метою вирішення цієї проблеми досліджували залежність електричної мічності, питомого об'ємного електричного опору, діелектричної проникності та тангенсу кута діелектричних втрат від кількості модифікаторів та властивостей інгредієнтів полімерних композичій. В ході дослідження використовували кополімер етилену з вінілацетатом. А також методи визначення електричної міцності, об'ємного електричного опору, тангенсу кута діелектричних втрат, діелектричної проникності.

Отримані результати показали, що електрична мічність суттєво підвищується до $32-35$ кB/мм у разі застосування в якості наповнювачів-антипиренівтригідратів оксиду алюмінію з меншим середнім діаметром часточок полімерної матриці КЕВ-1 та модифікатору 1. Під час використання полімерної матрищі КЕВ-2 найвищі показники (41 кB/мм) одержано для композицій з гідромагнезитом та модифікатором 2. Питомий об'ємний електричний опір мало змінюється для модифікованих полімерних композицій з використанням дигідрату оксиду магнію з меншим середнім розміром часточок та модифікатору 2 , а також для полімерних матриць КЕВ-1 $і$ КЕВ-2. Після впливу вологи питомий об'ємний електричний опір має максимальне значення 1,2·10 13 Ом·см для полімерної композицї на основі КЕВ-1, антипірену - тригідрат оксиду алюмінію та модифікатору 1. Діелектрична проникність та тангенс кута діелектричних втрат мають найкращі показники для полімерних композицій на основі КЕВ-1, гідромагнезиту та модифікатору $2\left(\varepsilon=3,3 ; \operatorname{tg}=6 \cdot 10^{-3}\right)$.

Завдяки цьому забезпечується можливість підвищення електрофізичних властивостей пожежобезпечних композицій для виготовлення ізоляції та оболонок кабельної продукції У порівнянні з аналогічними відомими матеріалами це забезпечує зниження витрат матеріалу за рахунок зменшення товщини та дає можливість підвищити економічну ефективність виробництва вогнестійких кабелів.

ключові слова: модифіковані полімерні композищї, кополімер етилену з вінілацетатом, наповнювачіантипірени, електрофізичні характеристики.

\section{Introduction}

To date, halogen-based polymeric compositions have been widely used in the cable industry. In recent years, technical requirements for cable products have increased and, as a result, the need to develop new advanced materials, including fireproof polymer composite materials. Composite fireproof materials of polyolefins are very promising. This is due to the growing use of wires and cables for the energy industry, nuclear energy, railway transport, construction, and so on. In these industries, fire safety requirements for cable materials are significantly higher than for general-purpose cables. Insulation and sheathing materials must comply with European standards. It is necessary to create special-purpose materials that meet specific operational needs - not the spread of combustion and the halogen-free, low smoke and low toxicity materials.

The creation of halogen-free formulations is achieved by introducing flame retardants - metal hydroxides into the base polymer. Aluminum hydroxides $\mathrm{Al}(\mathrm{OH})_{3}$ and magnesium $\mathrm{Mg}(\mathrm{OH})_{2}$, of synthetic and natural origin, hydromagnesites, have been used commercially. Processing of such materials causes difficulties, due to the high content of fillers, flame retardants. A modifier is used to regulate the rheological properties of polymer compositions [1].

The main technical characteristics for fireproof polymer compositions during operation are electrophysical characteristics. However, researching them is not enough. Therefore, the study of the dependence of electrophysical properties on the composition of polymer compositions, given the modifier, chemical composition, dispersion of fillers, flame retardants, is an actual problem.

\section{The object of research and its technological audit}

The object of research is the electrophysical properties of fireproof composite materials of ethylene - vinyl acetate copolymer, which include filler-flame retardants and modifiers. In order to ensure the incombustibility performance, polymer compositions have a high degree of filling up to $60 \%$ by weight. Polymer matrix is used a ethylene - vinyl acetate copolymer. Inorganic fillersflame retardants - aluminum oxide trihydrate, magnesium oxide dihydrate and hydromagnesite.

One of the most problematic places is to obtain stable electrophysical properties at such a high level of filling 
of the polymer composition. To ensure the level of electrophysical indicators, which corresponds to the regulatory documentation, the modifiers - aminosilanes - are introduced into the polymer compositions.

\section{The aim and objectives of research}

The aim of research is studying the changes in the electrophysical properties of fireproof composite materials: ethylene-vinyl acetate copolymer depending on the concentration of the modifier, type and dispersion of the flame retardant

To achieve this aim it is necessary to perform the following objectives:

1. Investigate the electrical strength of polymer compositions

2. Investigate the specific volume electrical resistance of polymer compositions.

3. Investigate the dielectric loss tangent and permittivity of polymer compositions.

\section{Research of existing solutions of the problem}

Analysis of the literature data shows that one of the means of reducing the flammability of polymeric materials of polyolefins is the introduction of filler-fire retardants into the polymer composition [2]. For this purpose, inorganic fillers-flame retardants are used [3]. In conditions of real fire, polyvinyl chloride (PVC) plastic compounds, which are elements of cables that have an oxygen index (OI) value of up to 40 units, are a source of release of corrosive gas of hydrogen chloride $(\mathrm{HCl})$ and significant smoke. Therefore, in order to solve the problems associated with the release of $\mathrm{HCl}$ and smoke, polymer compositions were created that do not emit corrosive gases and have a significantly lower level of smoke emission [4]. These materials not only increase the fire resistance due to the absorption of a larger amount of heat, but also neutralize acid gases, which leads to a decrease in smoke generation [5]. Polyolefins are commonly used as the polymer base, and aluminum oxide trihydrate, magnesium oxide dihydrate, and magnesites are used as flame retardants. This direction is dedicated to a significant amount of research. The mechanical and fire-resistant properties of composite materials to ethylene-vinyl acetate copolymer (EVA) and alumina trihydrate with different particle diameters were studied, and the change in these properties depending on the dispersity of the filler was determined [6]. The effectiveness of the use of calcium hydroxide with the aim of increasing the fire resistance of medium density polyethylene is shown [7]. The fireproof properties of composite materials are investigated, the base polymer in which is low-density polyethylene/ethylene-vinyl acetate copolymer (LDPE/EVA). Metal hydroxides (magnesium hydroxide and aluminum oxide trihydrate) are used as fillers for flame retardants. Refractory properties are assessed by horizontal combustion and oxygen index [8]. Using the methods of thermogravimetric analysis (TGA) and differential scanning calorimetry (DSC), polymer compositions are studied using magnesium dioxin as a flame retardant. The heat capacity of these materials is determined [9].

The fire resistance of ethylene copolymer with vinyl acetate, which is filled with metal hydroxides (aluminum oxide trihydrate and magnesium oxide dihydrate) and silicon dioxide, is investigated. It is noted that silica provides an advantage if the amount and other properties of fillers contribute to the formation of a protective mineral layer [10].

It is established that to ensure the fireproof properties of composite materials for insulation and cable sheaths and better safety of electrical equipment and devices, there must be a very high degree of filling of the polymer matrix with metal hydrates. This can lead to loss of flexibility and low mechanical properties with simultaneous problems during processing [11].

Possibility of using magnesium hydroxide, zinc borates and their joint action as an inhibitor of combustion of polypropylene fiber is investigated. The efficiency of using zinc borate is shown. The use of magnesium hydroxide is ineffective. Thermal, mechanical and morphological properties are tested [12].

The efficiency of using aminoalkoxysilanide as a coupling agent [13] to improve polymer-filler contacts in composite materials and process inorganic substrates to increase the adhesion of various polymers and coatings $[14,15]$ is shown.

Information on the use of aminoalkoxysilane to modify fireproof polymer compositions, including those based on ethylene-vinyl acetate copolymers, is practically absent in the literature.

These studies show that the properties of polymer compositions vary depending on the composition. The level of electrophysical properties of fireproof polymer composite materials during the operation of cable products is important. However, many issues related to the creation of fireproof polymer compositions are still not well understood. Especially it concerns the effect of the modifier, fillers-flame retardants and the polymer matrix on the electrical properties.

\section{Methods of research}

The copolymers of ethylene vinyl acetate (EVA-1, EVA-2) are investigated, the characteristics of which are given in Table 1, as well as filler-flame retardants, which used alumina trihydrate, magnesium oxide dihydrate, a mixture of magnesite and hydromagnesite.

Table 1

Characteristics of copolymers of ethylene with vinyl acetate (EVA)

\begin{tabular}{|l|c|c|}
\hline \multicolumn{1}{|c|}{ Indicator } & EVA-1 & EVA-2 \\
\hline Density, $\mathrm{kg} / \mathrm{m}^{3}$ & 939 & 951 \\
\hline Melt flow rate, $2.16 \mathrm{~kg}, \mathrm{~g} / 10 \mathrm{~min}$ & 2.5 & 5 \\
\hline Vinyl acetate content, \% & 18 & 28 \\
\hline
\end{tabular}

Characteristics of fillers-fire retardants are given in Table 2. Modifier 1 isaminosilane (3-aminopropyl-triethoxysilane) modifier 2 is aminosilane ( $\mathrm{N}$-(3-trimethoxysilane) propylbutylamine). Characteristics are given in Table 3.

The ingredients of the polymer compositions are weighed on the scales with an accuracy of $0.001 \mathrm{~g}$ and sequentially loaded onto the rollers. Temperature of the work


Samples are rolledin 3 minutes at a gap of $0.4-0.5 \mathrm{~mm}$. Then the gap is adjusted to $2 \mathrm{~mm}$. In the process of rolling periodically cut at least 2 times per minute. Last minute rolls without undercuts. 
Samples are conditioned at a temperature of $(293 \pm 2) \mathrm{K}$ for at least 24 hours.

Rollers have a friction of 1.5 .

Measurements of electrophysical indicators of polymer compositions are carried out on samples with a thickness of $(1.0 \pm 0.1) \mathrm{mm}$, manufactured by the roller-pressing method with $T=448 \mathrm{~K}$.

Table 2

Characteristics of fillers-fire retardants

\begin{tabular}{|c|c|c|c|c|c|}
\hline \multirow{2}{*}{ Indicator } & \multicolumn{2}{|c|}{$\mathrm{Al}(\mathrm{OH})_{3}$} & \multicolumn{2}{|c|}{$\mathrm{Mg}(\mathrm{OH})_{2}$} & \multirow{2}{*}{$\begin{array}{c}\begin{array}{c}\mathrm{Mg}\left(\mathrm{CO}_{3}\right)_{4}\left(\mathrm{OH}_{2} \cdot 4 \mathrm{H}_{2} \mathrm{O}\right. \\
\mathrm{Mg}_{3} \mathrm{Ca}\left(\mathrm{CO}_{3}\right)_{4}\end{array} \\
\text { Sample No. } 5\end{array}$} \\
\hline & $\begin{array}{c}\text { Sample } \\
\text { No. } 1\end{array}$ & $\begin{array}{l}\text { Sample } \\
\text { No. } 2\end{array}$ & \begin{tabular}{|c|} 
Sample \\
No. 3
\end{tabular} & $\begin{array}{l}\text { Sample } \\
\text { No. } 4\end{array}$ & \\
\hline \multicolumn{6}{|c|}{ Mass fraction, \%: } \\
\hline$-\mathrm{Mg}(\mathrm{OH})_{2}$ & - & - & $>93$ & $>93.2$ & 98.96 \\
\hline$-\mathrm{Al}(\mathrm{OH})_{3}$ & $>99.2$ & $>99.5$ & - & - & - \\
\hline$-\mathrm{SiO}_{2}$ & $<0.05$ & $<0.1$ & $<0.05$ & $2.2 \pm 0.2$ & 0.67 \\
\hline$-\mathrm{Fe}_{2} \mathrm{O}_{3}$ & $<0.035$ & $<0.03$ & $<0.3$ & $0.12 \pm 0.02$ & 0.04 \\
\hline$-\mathrm{Na}_{2} \mathrm{O}$ & $<0.6$ & $<0.4$ & $<0.05$ & - & $<0.05$ \\
\hline$-\mathrm{CaO}$ & - & - & - & $2.2 \pm 0.2$ & - \\
\hline \multicolumn{6}{|c|}{ Median particle diameter, microns: } \\
\hline - medium & 1.5 & 3 & 3 & 3.7 & 1.4 \\
\hline$-\underset{\left(D_{98}\right)}{\text { maximum }}$ & 3.6 & 18 & 20 & 12.5 & 8.35 \\
\hline$-\underset{\left(D_{10}\right)}{\text { minimum }}$ & 0.5 & 1 & 1 & 1.1 & 1.02 \\
\hline
\end{tabular}

Table 3

Characteristics of aminosilanes

\begin{tabular}{|l|c|c|}
\hline \multirow{2}{*}{ Indicator } & \multicolumn{2}{c|}{ Value } \\
\cline { 2 - 3 } & Aminosilane 1 & Aminosilane 2 \\
\hline Density, $\mathrm{kg} / \mathrm{m}^{3}, 20^{\circ} \mathrm{C}$ & 950 & 947 \\
\hline Dynamic viscosity, $\mathrm{mPa} \cdot \mathrm{s}, 20^{\circ} \mathrm{C}$ & 2 & 2.5 \\
\hline $\mathrm{pH}$ & 11.3 & 10.9 \\
\hline
\end{tabular}

A series of experiments to determine the electrical strength, electrical resistivity, permittivity, dielectric loss tangent was carried out using an AII-70 type apparatus (Russia), a KISI-1 resistance meter (Russia), and an AC bridge P589 (Russia).

Electrical resistivity is determined by the presence of free charges (electrons and ions) and their mobility.

Electric strength is electric field strength, the value of which occurs to breakdown - a measure of the electrical strength of a given material.

The permittivity of a composite material is determined by the ratio of the capacitance of an electrical capacitor, which is filled with a dielectric to the capacitance of the same capacitor in vacuum.

Dielectric losses understand a part of the energy of an electric field, which is irreversibly dissipated in a dielectric in the form of heat.

Processing of the results and plotting were performed using Microsoft Office Excel 2007 software.

The adequacy of the regression equation was carried out by checking the statistical significance of determina- tioncoefficient $R^{2}$ by the $F$-criterion determined by the formula [16]:

$$
F_{p}=\frac{R^{2}}{1-R^{2}} \cdot \frac{n-m-1}{m},
$$

where $n$ - the number of observations; $m$ - the number of factors in the regression equation.

\section{Research results}

Measurement of the electrical strength of polymer compositions is carried out with an alternating voltage of up to $50 \mathrm{kV}$ and a frequency of $50 \mathrm{~Hz}$.

The research results are shown in Fig. 1, 2.



Fig. 1. Dependence of electrical strength on the modifier content for EVA-1-based polymer compositions and flame retardants $(1,4,5)$ :

1, 2 - fire retardant $1 ; 3,4$ - fire retardant $4 ; 5$ - fire retardant 5

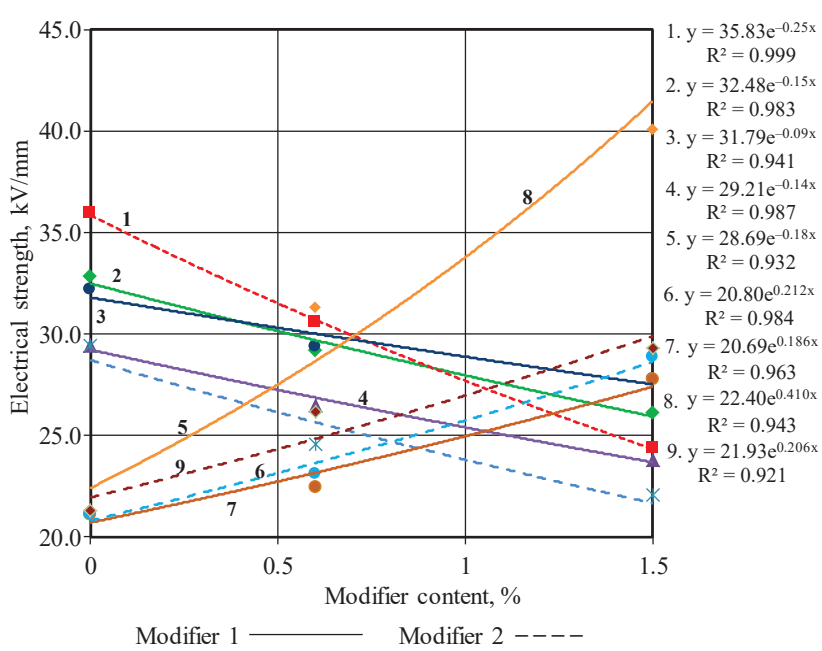

Fig. 2. Dependence of electrical strength on the modifier content for EVA-2-based polymer compositions and flame retardants (1-5): 1, 2 - fire retardant $1 ; 3$ - fire retardant $2 ; 4,5$ - fire retardant 3; 6, 7 - fire retardant 4; 8, 9 - fire retardant 5

The measurements of the volume electrical resistance are carried out using a KISI-1 cable insulation resistance meter with a voltage of $1000 \mathrm{~V}$.

The calculation of the specific volume electrical resistance is carried out according to the formula:

$$
\rho_{v}=\frac{\pi \cdot\left(\frac{d_{1}+d_{2}}{2}\right)^{2}}{4 \cdot t} \cdot R_{v},
$$


where $d_{1}$ - diameter of the measuring electrode, $\mathrm{m} ; d_{2}-$ internal diameter of the guard electrode, $\mathrm{m} ; t$ - the sample thickness; $R_{m}$ - measured resistance, Ohm.

The research results are shown in Fig. 3, 4.

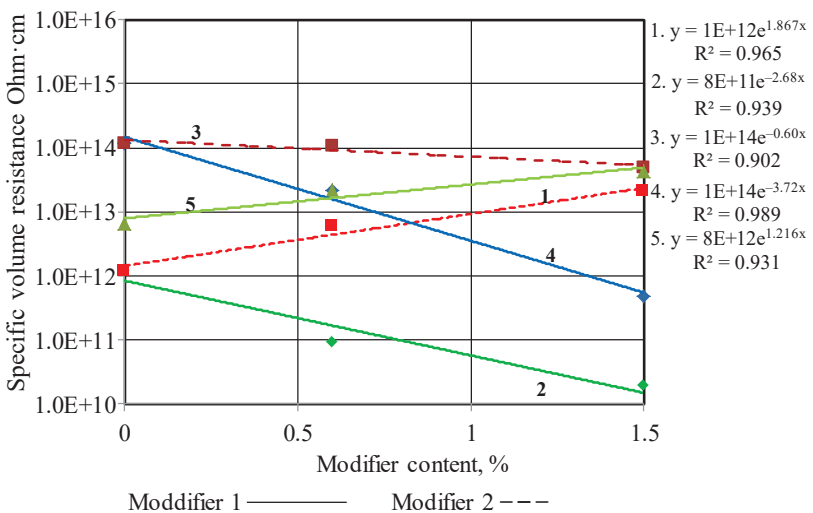

Fig. 3. Dependence of the specific volume resistance on the content of the modifier of EVA-1-polymer compositions based on EVA-1 $(1,4,5)$ : 1,2 - fire retardant $1 ; 3,4$ - fire retardant $4 ; 5$ - fire retardant 5

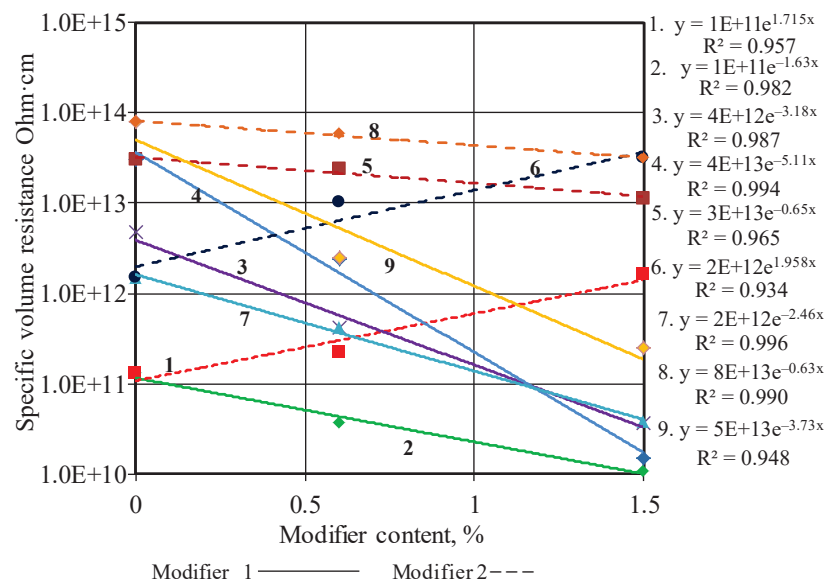

Fig. 4. Dpendence of the specific volume resistance on the content of the modifier EVA-2-based polymer compositions with flame retardants (1-5)

1,2 - fire retardant $1 ; 3$ - fire retardant $2 ; 4,5$ - fire retardant 3 , 6, 7 - fire retardant 4; 8, 9 - fire retardant 5

Polymer compositions contain inhomogeneities and impurities in the form of a second phase, resulting in a change in dielectric properties - the Maxwell-Vanger effect.

The most common type of inhomogeneitiesis the presence of voids. Under these conditions, the permittivity is simply reduced by the value, depending on the volume and distribution of air, which is located in them. A much greater effect can be expected from the presence of water in the insulating material. Such materials behave like three-dimensional grids, causing a contribution to the permittivity, which depends on the frequency and loss from the currents that occur in conductive isolated samples. Therefore, it is promising to study the specific volume resistance of polymer compositions after exposure to water, as a result of which the moisture content increases.

The research results are shown in Fig. 5-9.

Measurement of the dielectric loss tangent and electrical capacitance (for further calculation of the permittivity of the medium) was carried out using an AC bridge P589 at a voltage of $24 \mathrm{~V}$ and a frequency of $1 \mathrm{kHz}$ with an acceptable basic error of $\pm 0.1 \%$ when measuring capacitance and $\pm\left(0.02 \operatorname{tg} \delta+3 \cdot 10^{-4}\right)$ when measuring the tangent of dielectric loss angle.

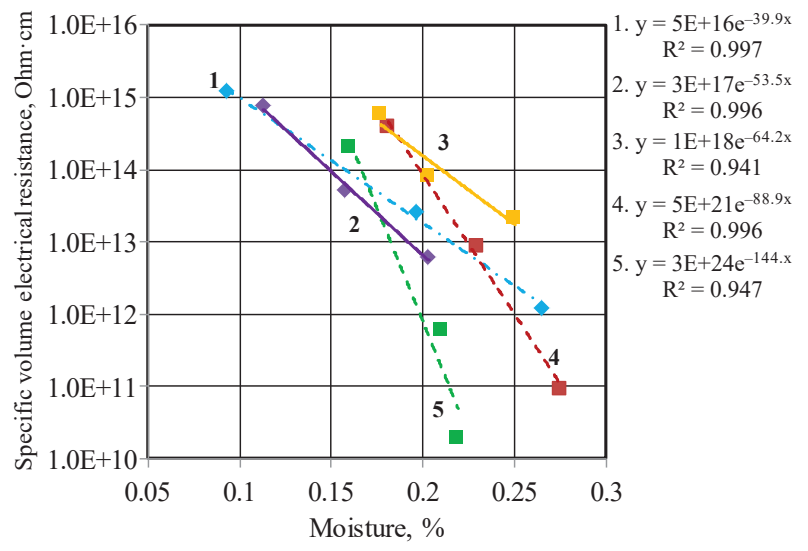

Fig. 5. Dependence of specific volume electrical resistance on moisture content of polymer compositions based on EVA-1 flame retardant (sample 1) and modifiers:

1 - without modifier; 2 - $0.6 \%$ modifier $1 ; 3-1.5 \%$ modifier 1 ; 4 - $0.6 \%$ modifier 2; 5 - $1.5 \%$ modifier 2

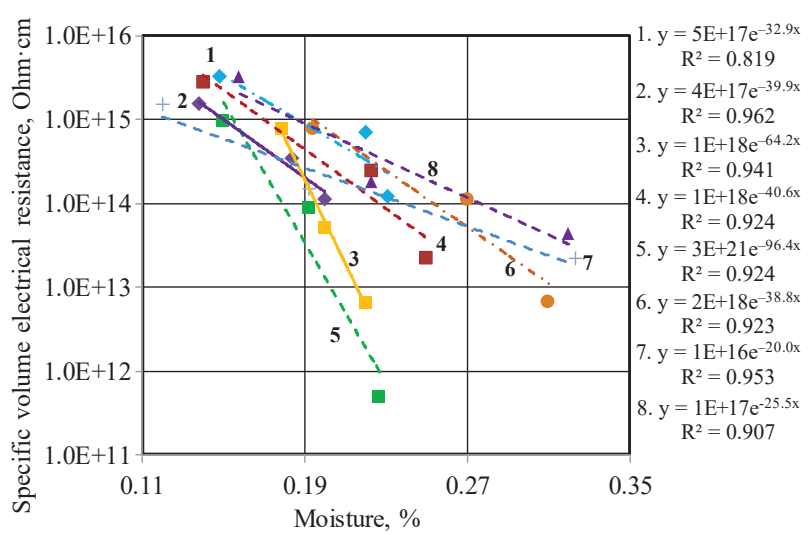

Fig. 6. Dependence of specific volume electrical resistance on moisture content of EVA-1-based polymer compositions based and flame retardant (sample 4) and modifiers:

1 - without modifier; 2 - $0.6 \%$ modifier $1 ; 3-1.5 \%$ modifier 1 ; 4 - $0.6 \%$ modifier 2; 5 - $1.5 \%$ modifier 2; flame retardant (sample 5) and modifier 2: 6 - without modifier; 7 - $0.6 \% ; 8-1.5 \%$

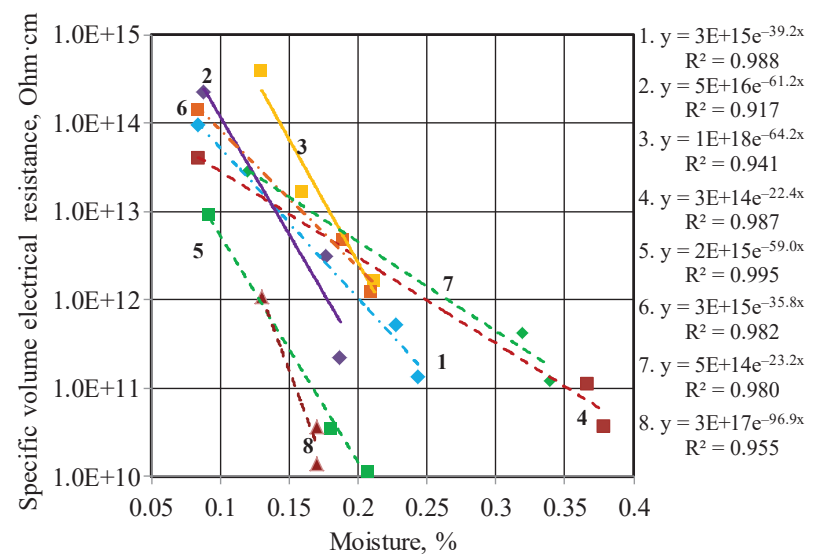

Fig. 7. Dependence of specific volume electrical resistance on the moisture content of EVA-2-based polymer compositions and flame retardant (sample 1) and modifiers:

1 - without modifier; 2 - $0.6 \%$ modifier $1 ; 3-1.5 \%$ modifier 1 ;

4 - $0.6 \%$ modifier 2; 5 - $1.5 \%$ modifier 2; flame retardant (sample 2) and modifier 2: 6 - without modifier; 7 - $0.6 \%$; 8 - $1.5 \%$ 


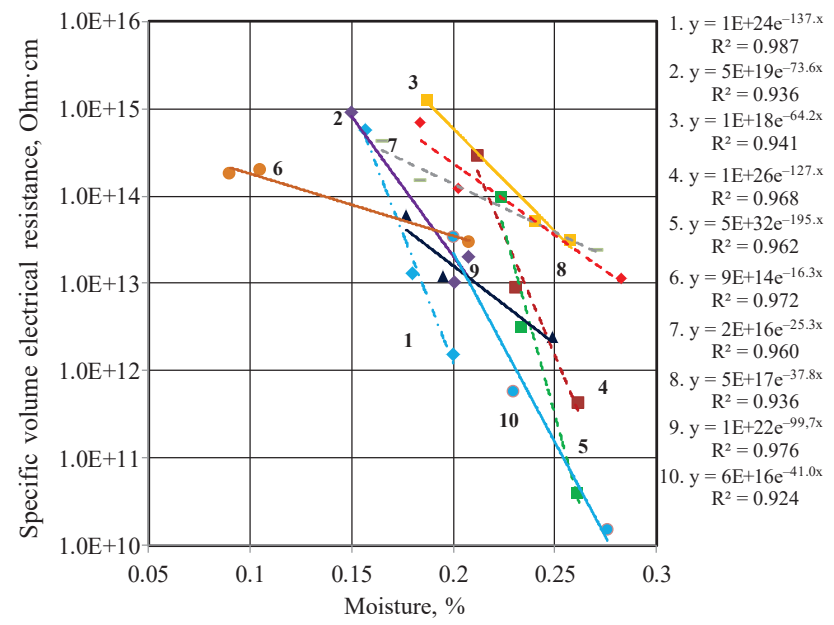

Fig. 8. Dependence of the specific volume electrical resistance on the moisture content of EVA-2-based polymer compositions and modifiers 1, 2 of flame retardants (sample 3) and modifiers: 1 - without modifier; $2-0.6 \%$ modifier 1 .

3 - $1.5 \%$ modifier 1; 4 - $0.6 \%$ modifier 2; 5 - $1.5 \%$ modifier 2 flame retardant (sample 4) and modifiers 6 - without modifier;

7 - $0.6 \%$ modifier 1; 8 - $1.5 \%$ modifier $1 ; 9$ - $0.6 \%$ modifier 2; $10-1.5 \%$ modifier 2

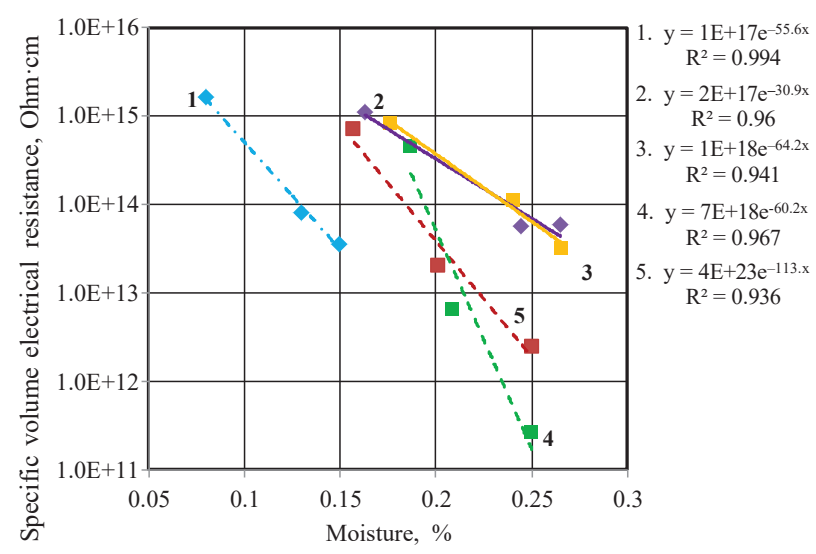

Fig. 9. Dependence of the specific volume electrical resistance on the moisture content of EVA-2-based polymer compositions and flame retardant (sample 5) and modifiers:

1 - without modifier; 2 - $0.6 \%$ modifier $1 ; 3-1.5 \%$ modifier 1 ; $4-0.6 \%$ modifier $2.5-1.5 \%$ modifier 2
The calculations were carried out according to the formulas: - permittivity of the medium:

$$
\varepsilon=0.144 \cdot C_{x} \cdot \frac{t}{\left(\frac{d_{1}+d_{2}}{2}\right)^{2}},
$$

where $d_{1}$ - the diameter of the measuring electrode, $\mathrm{m} ; d_{2}-$ internal diameter of the guard electrode, $\mathrm{m} ; t$ - the sample thickness; $C_{x}-$ measured electrical capacitance, $\mathrm{pF}$.

- the dielectric loss tangent:

$$
\operatorname{tg} \delta=\frac{1}{\omega \cdot C_{\text {par. }} \cdot R_{\text {par. }}}=\omega \cdot C_{\text {seq. }} \cdot R_{\text {seq. }},
$$

where $\omega$ - the angular frequency, $\mathrm{rad} / \mathrm{s} ; C_{\text {par }}$ - measured electrical capacitance in an equivalent parallel equivalent circuit, $\mathrm{pF} ; R_{\text {par }}$ - measured resistance in the equivalent parallel equivalent circuit, Ohm; $C_{\text {seq. }}$ - measured electrical capacitance in equivalent sequential equivalent circuit, $\mathrm{pF} ; R_{\text {seq. }}$ - measured resistance in equivalent parallel equivalent circuit, $\mathrm{Ohm}$.

The research results are shown in Fig. 10-13.

An insulating material is considered to be better, the higher its electrophysical properties. Electrophysical properties are characterized by the values of resistivity, dielectric strength (penetration strength), permittivity and dielectric loss. The values of these characteristics and their dependence on aggressive factors (in particular, moisture absorption), temperature and frequency of the electric field determine the choice of insulating polymer compositions.

The study of the dependences of the electrical strength of polymer compositions on the chemical composition and dispersion of fillers-flame retardants demonstrates the influence of each of them on its value. The analysis of these characteristics shows that high values of the electrical strength can be achieved when used as fillers-flame retardants of aluminum oxide trihydrate. For EVA-1-based polymer compositions $-27-27.5 \mathrm{kV} / \mathrm{mm}$ (samples 1,2 ). For EVA-2-based polymer compositions - 32-35 kV/mm. EVA-2-based polymer compositions- 2 with a large indicator of polymer flowability have large values of electrical strength than EVA-1. This can be explained better by the adhesive properties of the polymer matrix relative to the filler and the uniform distribution of the ingredients of composite materials in supramolecular formations.

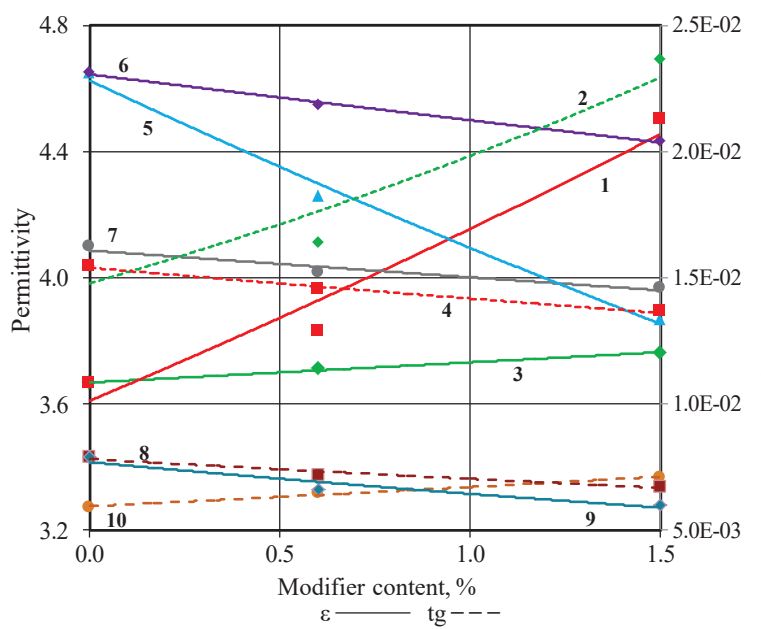

$$
\begin{aligned}
& \text { 1. } y=0.014 \mathrm{e}^{0.293} \\
& R^{2}=0.921 \\
& \begin{aligned}
\text { 2. } y=0.015 \mathrm{e}^{-0.08 x} \\
\mathrm{R}^{2}=0.990
\end{aligned} \\
& \mathrm{y}=3.610 \mathrm{e}^{0.14} \\
& \begin{array}{c}
y=3.610 e^{0} \\
R^{2}=0.96
\end{array} \\
& \begin{array}{c}
\mathrm{R}^{2}=0.96 \\
\text { 苛 } 4 . \mathrm{y}=3.667 \mathrm{e}^{0.017 \mathrm{x}}
\end{array} \\
& \text {. } \begin{array}{c}
\mathrm{y}=3.667 \mathrm{e}^{0.017 x} \\
\mathrm{R}^{2}=0.990
\end{array} \\
& \text { I 5. } \mathrm{y}=4.624 \mathrm{e}^{-0.12 \mathrm{x}} \\
& \text { की } \quad \mathrm{R}^{2}=0.991 \\
& \text { 6. } y=4.643 \mathrm{e}^{-0.03} \mathrm{R}^{2}=0.992 \\
& \text { E 7. } \mathrm{y}=4.085 \mathrm{e}^{-0.02 \mathrm{x}} \\
& \text { 跣 }=0.934 \\
& \text { 8. } \mathrm{y}=0.007 \mathrm{e}^{-0.10 \mathrm{x}} \\
& \mathrm{R}^{2}=0.950 \\
& \text { 9. } \mathrm{y}=0.007 \mathrm{e}^{-0.17} \\
& \begin{array}{c}
\mathrm{R}^{2}=0.914 \\
\text { 10. } \mathrm{y}=0.005 \mathrm{e}^{0.120 \mathrm{x}}
\end{array} \\
& \mathrm{R}^{2}=0.990
\end{aligned}
$$

Fig. 10. Dependence of permittivity and dielectric loss tangent of EVA-1-based polymer compositions and flame retardants $1,4,5$ on the content of modifiers: 1, 4, 6, 8 - modifier 1; 2, 3, 5, 7, 9, 10 - modifier 2; 1-4 - fire retardant 1; 5-8 - fire retardant 4; 9, 10 - fire retardant 5 


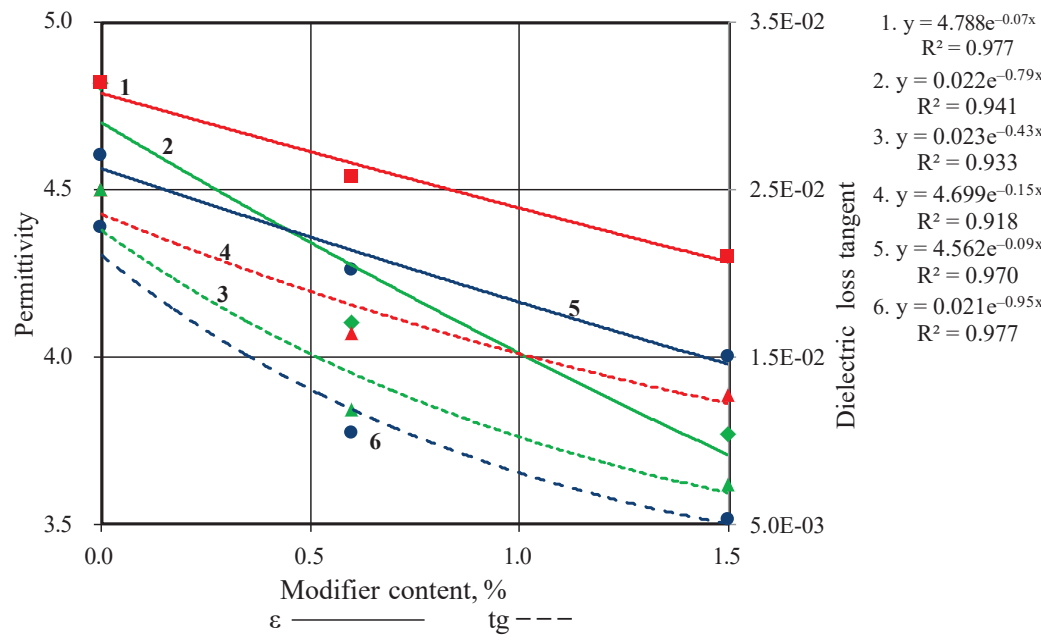

Fig. 11. Dependence of permittivity and dielectric loss tangent of EVA-2-based polymer compositions and flame retardants 1,2 on the content of modifiers: 1,4-modifier 1;

$$
\text { 2, 3, 5, } 6 \text { - modifier 2; 1-4 - fire retardant } 1 ; 5-6 \text { - fire retardant } 2
$$

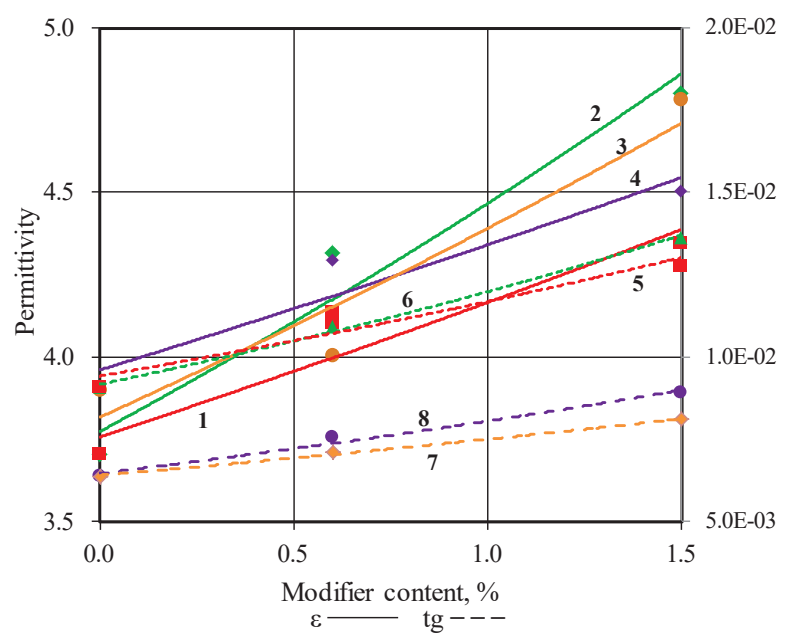

$$
\begin{aligned}
& \text { 1. } \mathrm{y}=3.756 \mathrm{e}^{0.103 \mathrm{x}} \\
& \mathrm{R}^{2}=0.927 \\
& \text { 2. } y=3.772 \mathrm{e}^{0.169 x} \\
& \mathrm{R}^{2}=0,953
\end{aligned}
$$

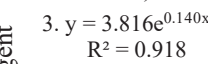

$$
\begin{aligned}
& \text { 4. } y=3.959 \mathrm{e}^{0.092 x} \\
& \mathrm{R}^{2}=0.907
\end{aligned}
$$

Fig. 12. Dependence of permittivity and dielectric loss tangent of EVA-2-based polymer compositions and flame retardants 3, 4 on the content of modifiers: 1, 3, 5, 7 -modifier 1 $2,4,6,8$ - modifier 2; 1, 2, 5, 6 - fire retardant 3; $3,4,7,8$ - fire retardant 4



1. $\mathrm{y}=0.014 \mathrm{e}^{-0.2}$ $\mathrm{R}^{2}=0.925$

2. $\mathrm{y}=4.111 \mathrm{e}^{-0.03}$

3. $y=4.097 \mathrm{e}^{-0.03}$ $\mathrm{R}^{2}=0.968$

4. $y=0.017 \mathrm{e}^{-1.73}$ $\mathrm{R}^{2}=0.975$

Fig. 13. Dependence of permittivity and dielectric loss tangent of EVA-2-based polymer compositions and flame retardant 5 on the content of modifiers:

1, 4 -modifier 1; 2, 3 -modifier 2
When used as fillers for magnesium oxide dihydrate, the dielectric strength decreases to $25 \mathrm{kV} / \mathrm{mm}$ for polymer compositions based on EVA-1 and to $29-31 \mathrm{kV} / \mathrm{mm}$ for EVA-2-based polymer compositions. It should be noted that the use of fillers-flame retardant with a smaller average particle diameter affects the increase in this indicator. When using hydromagnetics as a filler, the dielectric strength decreases to $19-21 \mathrm{kV}$, respectively.

It should be noted that the qualitative composition and the amount of the modifier - aminosilanes have a significant influence on the value of electric strength. For EVA-1-based polymer compositions (Fig. 1), the dielectric strength increases for all flame retardants. Significant increase occurs when using modifier 1 (with a lower dynamic viscosity).

For EVA-2-based polymer compositionswith a flow index of $5.0 \mathrm{~g} / 10 \mathrm{~min}$, the dielectric strength decreases when using aluminum oxide trihydrate (sample 1,2) and magnesium oxide dihydrate (sample 3 ). When using magnesium oxide dihydrate with a large average particle size (sample 4) and hydromagnesite (sample 5), the dielectric strength increases with an increase in the number of modifiers 1 and 2 .

The study of the influence of the chemical composition of the dispersity of fillers-flame retardants and the quantity and quality of modifiers shows the change in the specific electrical volume resistance of polymer compositions. When used as a EVA-1 polymer matrix, the specific electrical volume resistance decreases for polymer compositions by placing aluminum oxide trihydrate and magnesium oxide dihydrate and modifier 1 with a lower dynamic viscosity (2.0 MPa $\cdot \mathrm{s})$. And it increases when using modifier 2 with a higher dynamic viscosity (2.5 MPa.s). For polymer compositions, placing the fire retardant 5 , the specific electrical volume resistance increases significantly from $1 \cdot 10^{13}$ to $0.8 \cdot 10^{14} \mathrm{Ohm} \cdot \mathrm{cm}$ and exceeds the value of this indicator without the introduction of modifier 1.

The specific volume electrical resistance of EVA-2-based polymer compositions is reduced for all fillers-flame retardant when using modifier 1 with a lower dynamic viscosity. When modifier 2 is used, it changes little, and in the case of use as fillers, aluminum oxide trihydrate with a smaller average particle diameter and magnesium oxide dihydrate with a large average particle diameter increases 10 times.

The changes in the specific volume electrical resistance from the moisture of polymer compositions with different contents of modifiers 1 and 2 are investigated. A decrease in the specific volume electrical resistance 
for all polymer compositions with increasing humidity, both with and without modifiers, is shown.

EVA-1polymer compositions are investigated. When using aluminum oxide trihydrate (sample 1, Fig. 5), a significant decrease in this indicator is observed when using the modifier 1 from $1.0 \cdot 10^{15}$ to $1.0 \cdot 10^{11}$ and $1.6 \cdot 10^{10} \mathrm{Ohm} \cdot \mathrm{cm}$ (curves 4, 5). If using modifier 2, then the decrease in specific volume electrical resistance decreases by an order of magnitude. The moisture content of $0.25 \%$ and the content of the modifier $1.5 \%$ specific volume electrical resistance exceeds the value for the unmodified polymer composition. When using magnesium oxide dihydrate (sample 4) and hydromagnesite (sample 5), polymer compositions with modifier 2 have the best value. For example, for hydromagnesite (curve 8), the specific volume electrical resistance increases compared to the unmodified polymer composition sample from $1.0 \cdot 10^{13}$ up to $1.6 \cdot 10^{13} \mathrm{Ohm} \cdot \mathrm{cm}$, moisture content $0.31 \%$.

If EVA-2 polymer matrix is used, then the main trend of decreasing the specific volume electrical resistance from humidity remains, however, it moves to the region of lower values (Fig. $7-9$ ).

Important electrical characteristics for fireproof polymer compositions are permittivity and dielectric loss tangent. Therefore, let's investigate the change in these parameters from the chemical composition and dispersion of fillers-flame retardants and the qualitative and quantitative content of the modifiers 1, 2. The electrically insulating material is considered the better, the lower the permittivity and the dielectric loss tangent. Thus, for EVA-1-based polymer compositions (Fig. 10), the best performance in dielectric permeability is a composition with a smaller average particle size of the filler-flame retardant aluminum oxide trihydrate (curve 3, sample 1) or magnesium oxide dihydrate and modifier 2 , and also magnesium oxide dihydrate (curve 7 , sample 4). This indicator practically does not change with an increase in the modifier content.

The permittivity changes little when used as a filler-flame retardant hydromagnesite and modifier 2 (curve 9). When using the modifier 1, this indicator increases significantly.

Also, the trend is observed for the dielectric loss tangent for all EVA-1-based polymer compositions.

EVA-2-based polymer compositions with a flow index of $5 \mathrm{~g} / 10 \mathrm{~min}$. Research results show that with the use of aluminum oxide trihydrate and modifiers 1,2 , the permittivity index and the dielectric loss tangent are improved and moved to lower values (Fig. 11). Moreover, large values of these indicators are obtained using modifier 2 (curves 3, 4, 6).

The use of modifiers 1, 2 in polymer compositions containing magnesium oxide dihydrate leads to a deterioration of the permittivity and the tangent of dielectric loss (Fig. 12). But in the case of the use of flame retardant (sample 4) with a smaller average diameter of particles and modifiers 1, 2, the tangent of dielectric loss practically differs little from the unmodified composition (curve 7,8 ).

The use of hydromagnesite as a filler-flame retardant (Fig. 13) shows a significant effect on the improvement of the permittivity and the tangent of dielectric loss angle. The permittivity decreases to 3.9 , and the dielectric loss tangent decreases to $1.0 \cdot 10^{-3}$ in the presence of modifier 1 in an amount of $1.5 \%$.

An important influence on the electrophysical properties of fireproof polymer compositions provides for the formation of the supramolecular structure of the obtained compositions. This is evidenced by the results of studies of electrical strength, specific volume electrical resistance, permittivity and tangent of dielectric loss angle.

\section{SWOT analysis of research results}

Strengths. The advantages of this research are the study of the electrophysical properties of fireproof polymer composite materials using high-precision modern methods. The obtained results provide a comparative assessment of the electrophysical properties when using the ingredients of polymer compositions with different physicochemical properties and modifying their aminosilanes. This makes it possible to increase the electrical properties of fireproof compositions for the manufacture of insulation and cable sheaths compared with similar known materials, this reduces material consumption by reducing thickness and makes it possible to increase the economic efficiency of production of fireresistant cables.

Weaknesses. The ingredients of polymer compositions must be imported because they are not produced in Ukraine.

Opportunities. The research results allow the development of technologies for the production of polymer compositions with controlled electrophysical properties for insulation and cable sheaths.

Research can use manufacturers of polymeric materials around the world.

Threats. It is necessary to master the technological process of production, personnel training in the management of the technological process.

\section{Conclusions}

1. Changes in the electrophysical properties of fireproof composite materials, ethylene copolymer with vinyl acetate are studied depending on the modifier concentration, type and dispersion of the flame retardant filler. The physical strength of fireproof compositions is significantly influenced by the physicochemical properties of fire retardant fillers and modifiers. Electric strength significantly increases up to $32-35 \mathrm{kV} / \mathrm{mm}$ in the case of use as fillers-flame retardants of aluminum oxide trihydrate with a smaller average particle diameter of the EVA-1-based polymer matrix and modifier 1 . When using the EVA-2-based polymer matrix, high rates $(41 \mathrm{kV} / \mathrm{mm})$ obtained for compositions with hydromagnesite and modifier 2 .

2. It is shown that the specific volume electrical resistance varies little for modified polymer compositions using magnesium oxide dihydrate with a smaller average particle size and modifier 2 for the polymer matrixes EVA-1 and EVA-2. After exposure to moisture, the specific volume electrical resistance has a maximum value of $1.2 \cdot 10^{13} \mathrm{Ohm}$ $\mathrm{cm}$ for the EVA-1-based polymer, the flame retardant is aluminum oxide trihydrate and modifier 1.

3. It is determined that the permittivity and dielectric loss tangent have the best performance for EVA-1-based polymer compositions, hydromagnesite and modifier 2 $\left(\varepsilon=3.3 ; \operatorname{tg}=6 \cdot 10^{-3}\right)$.

\section{References}

1. Chulieieva O. Development of directed regulation of rheological properties of fire retardant composite materials of ethylene vinyl acetate copolymer // Technology audit and production reserves. 2017. Vol. 2, Issue 1 (40). P. 25-31. doi: https:// doi.org/10.15587/2312-8372.2018.129699 
2. Chuleeva E. V., Zolotarev V. M., Chuleev V. L. Napolniteliantipireny. Teplofizicheskie svoystva // Khimichna promyslovist Ukrainy. 2016. Issue 3-4. P. 65-69.

3. Thermal study of low-grade magnesium hydroxide used as fire retardant and in passive fire protection / Formosa J. et. al. // Thermochimica Acta. 2011. Vol. 515, Issue 1-2. P. 43-50. doi: https://doi.org/10.1016/j.tca.2010.12.018

4. Obzor mineral'nyh antipirenov-gidroksidov dlya bezgalogennyh kabel'nyh kompoziciy // Kabel'-news. 2009. Issue 8. P. 41-43.

5. Ableev R. Aktual'nye problemy $\mathrm{v}$ razrabotke i proizvodstve negoryuchih polimernyh kompaundov dlya kabel'noy industrii // Kabel'-news. 2009. Issue 6-7. P. 64-69.

6. Chulieieva O. Effect of flame retardant fillers on the fire resistance and physicalmechanical properties of polymeric compositions // Eastern-European Journal of Enterprise Technologies. 2017. Vol. 5, Issue 12 (89). P. 65-70. doi: https://doi.org/ 10.15587/1729-4061.2017.112003

7. Calcium-based hydrated minerals: Promising halogen-free flame retardant and fire resistant additives for polyethylene and ethylene vinyl acetate copolymers / Laoutid F. et. al. // Polymer Degradation and Stability. 2013. Vol. 98, Issue 9. P. 1617-1625. doi: https://doi.org/10.1016/j.polymdegradstab.2013.06.020

8. Effect of Amino alcohol functionalized polyethylene as compatibilizer for LDPE/EVA/clay/flame-retardant nanocomposites / Lujan-Acosta R. et. al. // Materials Chemistry and Physics. 2014. Vol. 146, Issue 3. P. 437-445. doi: https://doi.org/10.1016/ j.matchemphys.2014.03.050

9. Chulieieva O. Effect of fire retardant fillers on thermophysical properties of composite materials of ethylene-vinyl acetate copolymer // Eastern-European Journal of Enterprise Technologies. 2017. Vol. 6, Issue 12 (90). P. 58-67. doi: https:// doi.org/10.15587/1729-4061.2017.119494

10. Fire retardant benefits of combining aluminum hydroxide and silica in ethylene-vinyl acetate copolymer (EVA) / Sonnier R. et. al. //
Polymer Degradation and Stability. 2016. Vol. 128. P. 228-236. doi: https://doi.org/10.1016/j.polymdegradstab.2016.03.030

11. Chang M.-K., Hwang S.-S., Liu S.-P. Flame retardancy and thermal stability of ethylene-vinyl acetate copolymer nanocomposites with alumina trihydrate and montmorillonite // Journal of Industrial and Engineering Chemistry. 2014. Vol. 20, Issue 4. P. 1596-1601. doi: https://doi.org/10.1016/j.jiec.2013.08.004

12. Jeencham R., Suppakarn N., Jarukumjorn K. Effect of flame retardants on flame retardant, mechanical, and thermal properties of sisal fiber/polypropylene composites // Composites Part B: Engineering. 2014. Vol. 56. P. 249-253. doi: https:// doi.org/10.1016/j.compositesb.2013.08.012

13. Chemical modification of henequén fibers with an organosilane coupling agent / Valadez-Gonzalez A. et. al. // Composites Part B: Engineering. 1999. Vol. 30, Issue 3. P. 321-331. doi: https://doi.org/10.1016/s1359-8368(98)00055-9

14. Effect of N-2-(aminoethyl)-3-aminopropyltrimethoxysilane surface modification and C.I. Acid Red 18 dye adsorption on the physicochemical properties of silica precipitated in an emulsion route, used as a pigment and a filler in acrylic paints / Jesionowski T. et. al. // Dyes and Pigments. 2003. Vol. 57, Issue 1. P. 29-41. doi: https://doi.org/10.1016/s0143-7208(03)00006-8

15. Juvaste H., Iiskola E. I., Pakkanen T. T. Aminosilane as a coupling agent for cyclopentadienyl ligands on silica // Journal of Organometallic Chemistry. 1999. Vol. 587, Issue 1. P. 38-45. doi: https://doi.org/10.1016/s0022-328x(99)00264-8

16. Makarova N. V., Trofimec V. Ya. Statistika v Excel: ucheb. pos. Moscow: Finansy i statistika, 2002. 368 p.

Chulieieva Olena, PhD, Director of the Science and Technology Center, PJSC «Yuzhcable Works», Kharkiv, Ukraine, ORCID: http:// orcid.org/0000-0002-7310-0788, e-mail: echuleeva@ukr.net 